\title{
The Role of Vegetables and Legumes in Assuring Food, Nutrition, and Income Security for Vulnerable Groups in Sub-Saharan Africa
}

\author{
Chris Ojiewo, Dyno J. D. H. Keatinge, Jaqueline Hughes, Abdou Tenkouano, \\ Ramakrishnan Nair, Rajeev Varshney, Moses Siambi, Emmanuel Monyo, \\ NVPR Ganga-Rao, and Said Silim
}

\begin{abstract}
Rising food and nutritional insecurity threatens the livelihoods of millions of poor people, particularly in sub-Saharan Africa. Vegetable and legume production and consumption are a potent mechanism for small-scale, disadvantaged farmers to obtain the required nutrients in their diets and to generate much-needed income through trade. Vegetables and legumes are key sources of nutrients and health-promoting phytochemicals, providing higher micronutrient contents and a wider spectrum of essential compounds to meet nutritional and health needs than other food sources. Diversifying diets with vegetables and legumes is a cheaper, surer, and more sustainable way to supply a range of nutrients to the body and combat malnutrition and associated health problems than other approaches that target only a single or a few nutritional factors. Furthermore, vegetables and legumes often accompany staple crops in meals, and most staple crops are less palatable without vegetable or legume accompaniments. As a growing world population demands more and higher quality foods, and as environmental problems such as soil degradation, water scarcity, biodiversity loss, and climate change become more acute, the need for innovative vegetable and legume research solutions to improve food and nutritional security cannot be overemphasized.
\end{abstract}

KEY WORDS: nutrition, income security, vegetables

\section{Introduction}

In 2013, an estimated 842 million people were suffering from chronic hunger, down from 868 million in 2012. Although this reduction is promising, the number of hungry people remains alarmingly high (Food and Agriculture Organization, 2013). Of the 842 million hungry people, 98 percent live in developing regions (Food and Agriculture Organization, 2013). While chronic hunger figures seem to be going down, more than 2 billion are still undernourished. In sub-Saharan Africa, food demand has continued to exceed supply while micronutrient deficiencies have aggravated the problem of food security (Food and Agriculture 
Organization, 2013). Siegel, Ali, Srinivasan, Nugent, and Venkat Narayan (2014) recently conducted a study on the supply:need ratio for vegetables and fruits and reported that sub-Saharan African countries-including Eritrea (0.05), Chad (0.09), Burkina Faso (0.10), Mozambique (0.12), and Ethiopia (0.12)—had the greatest shortages. This particularly affects women and children in the region. Poor maternal and child dietary habits, poor household economic status leading to the inability to obtain nutritious food, as well as poor maternal education and awareness of sources of critical nutrients in food are some of the predominant causes of undernutrition (Bellete, 2005). Improving and diversifying agricultural production, notably with vegetables and legumes, coupled with education on healthy nutrition, good eating habits, food preparation, and safe handling are effective strategies for overcoming malnutrition and chronic diet-related diseases such as excess weight and obesity, diabetes, hypertension, and cardiovascular diseases (Food and Agriculture Organization, 2007a). Additionally, this can contribute to poverty alleviation through additional income from sales and increased employment opportunities (Schreinemachers, Nagaraj, Hughes, \& Keatinge, 2014). However, all such interventions rely on a policy environment beneficial to horticulture if they are to be effective. Such policies, for example, include specific regional legislation that would be favorable to the easy release and quality maintenance of the seed of improved varieties. This is being pursued successfully at present by the African Seed Trade Association (AFSTA) and Economic Community of West African States (ECOWAS). It remains evident that the older colonial legislation regarding variety release remaining in law in many countries, though appropriate for field crops such as maize, is most inappropriate for crops with only small national markets. Such is usually the case with vegetables such as tomato, cabbage, and indigenous vegetables. This discourages investment by the private sector in developing the horticultural seed sector. Likewise, as use of input levels into agriculture such as fertilizer and irrigation water is much lower in Africa than in other comparable parts of the world, policy opportunities to encourage the use of local water associations and the promulgation of appropriate fertilizer stockists are urgently required. Twomlow et al. (2011) have clearly indicated that even small amounts of good quality fertilizer and seed can substantially improve productivity in field crops and this finding will be just as true for vegetables and legumes. Likewise, Woltering, Pasternak, and Ndjeunga (2011) have demonstrated that solar pumping and trickle irrigation can be the key to successful market gardening in the Sahelian region of West Africa. Policy initiatives to encourage the better use of such inputs have the potential to substantially improve the horticultural sector.

\section{Methods, Limitations, and Bias}

This synthesis article highlights major efforts, achievements, lessons learned, challenges, and gaps in the process of mainstreaming nutrient-dense vegetables and legumes-especially those traditionally referred to infamously as "orphaned crops"-into production, utilization, and marketing systems for food, nutrition, 
and income security of vulnerable groups in sub-Saharan Africa. For "orphaned vegetables," most of these efforts and achievements are credited to AVRDC-The World Vegetable Center-together with its various partners along the vegetable value chain in the region. For the "orphaned legumes," credit goes to the International Crops Research Institute for the Semi-Arid Tropics (ICRISAT) together with its network of national and international partners working in the region. A significant portion of literature cited and reported data is unpublished work stemming from major projects hosted by the two institutions at various times.

For example, AVRDC hosted a large project on "Promotion of Neglected Indigenous Leafy and Legume Vegetable Crops for Nutritional Health in Eastern and Southern Africa" (ProNIVA) between 2003 and 2006 (Phase 1) and 2006 and 2009 (Phase 2). The project generated information on baseline and impact of sociocultural and economic factors affecting farmers' practices, knowledge, skills, production, and income generation and marketing of neglected indigenous and legume vegetables as well as trends. Biodiversity of priority indigenous and legume vegetables were collected, characterized, described, and safeguarded. Agronomic data on production technologies of selected indigenous and legume vegetables were tested on-farm and on-station, developed, adapted, and made available to target groups. Data on intrinsic nutritional values of the germplasm were made available through literature surveys and validated in the nutrition laboratories of AVRDC. Aggressive awareness creation on the production and utilization practices and nutritional value of micronutrient-rich vegetables and associated health benefits was carried out. This resulted in demand creation and indigenous vegetable farmers were linked to niche markets including hotel chains and supermarkets. In addition, high-quality seed of lines preferred and selected by stakeholders-mainly smallholder farmers-was made available for increased production and subsequent utilization. This project was a precursor of another project "Vegetable Breeding and Seed Systems for Poverty Reduction in Africa (vBSS)" (2007-10), which led to official release and registration of various vegetable varieties. Results from these two projects together with some of their precursors and successors form the bulk of vegetable-related literature cited here.

ICRISAT has been hosting a large tropical legumes improvement project with two major CGIAR collaborators-CIAT and IITA-and a large host of national partners from sub-Saharan Africa. Focusing on chickpea, pigeonpea, groundnuts, soybean, common bean, and cowpea, the Tropical Legumes Project 1 and 2 (TL I and TL II) have exploited the improved germplasm that already existed, by using "fast-track" evaluation and seed production; encouraged farmer-participatory varietal selection; developed improved crop cultivars (including hybrids in the case of pigeonpea) by combining conventional plant breeding with modern breeding tools and techniques developed at the participating institutes. Launched in 2007, the TL II project is moving to a third phase this year with a major focus on fast-tracking release of varieties developed in earlier phases and technology dissemination. ICRISAT also hosts the CGIAR Research Program on Grain 
Legumes with work packages covering crop improvement of chickpea, pigeonpea, groundnuts, lentils, faba bean, common bean, cowpea, and soybean. Work done on these crops form the bulk of the literature cited with a major focus on chickpea and pigeonpea, which were traditionally considered "orphaned crops."

This synthesis article includes limited literature on the major legume and other staple crops too as examples that can be referred to in the process of mainstreaming orphaned crops. Although the focus area is sub-Saharan Africa, some of the orphaned crops mentioned here such as chickpea and pigeonpea are more important in Eastern and Southern Africa than Western and Central Africa. A significant portion of the literature cited includes unpublished work on the "orphaned" vegetables and legumes to highlight the progress made and information gap on the crops. Research gaps and other areas of emphasis along the value chains in the process of mainstreaming the orphaned vegetables and legumes into production and utilization systems for improved livelihoods have also been highlighted with emphasis on nutrition security.

\section{Food Security Through Production of Vegetables and Legumes}

The Green Revolution of the 1950s and 1960s was responsible for a dramatic increase in the world food supply due to development and deployment of more productive varieties of wheat and rice primarily in Asia and Latin America. In the recent past, new efforts to replicate the Green Revolution in sub-Saharan Africa have been launched on staple starch crops such as rice, maize, wheat, and cassava with the hope of eradicating poverty and food insecurity. Alliance for Green Revolution in Africa (AGRA) has robust programs focusing on Soils, Seeds, Policies, and Markets with other cross-cutting interventions that ensure integration across the agricultural value chains. While these efforts are appreciable, Tenkouano (2011) argues that an abundance of these crops will only amount to a "Grain Revolution" and not the "Revolution with Greens" needed to bring in sufficient, quality vegetables, and legumes required as part of a balanced diet.

With long cropping cycles, staple crops tend to be more vulnerable to environmental threats and risk of crop failure. In contrast, vegetables and legumes have shorter cycles, are faster growing, require little space, and thus can be considered less risk-prone. Besides, vegetable and legume harvests consumed at home supply the micronutrient and less expensive nonanimal source protein needs of these less fortunate people and surpluses can be sold to generate family income (Schreinemachers et al., 2014). An increased shift toward consumption of legume instead of animal protein would reduce pressure on natural resources and benefit the environment (Pimentel \& Pimentel, 2003). Most poor people in sub-Saharan Africa obtain the highest proportion of their total dietary protein from legumes: Burundi (45 percent); Rwanda (38 percent); Uganda and Kenya (20 percent); Comoros and Eritrea (18 percent); Niger, Ethiopia, Malawi, Angola, Tanzania (14-15 percent); Mauritania, Sierra Leone, Mozambique, Cameroon (12-13 percent); and Togo and Botswana (10-11 percent) (Akibode \& Maredia, 2011). 
Production of vegetables and legumes helps intensify cropping systems by utilizing underexploited production niches, serving as rotation-, inter-, and double-crops with cereals. Vegetables and legumes can be grown in small spaces such as backyard or home gardens with minimal resource application (Keatinge et al., 2012). Leaves, tender pods, and immature grains of some legumes (such as snap bean, chickpea, pigeonpea, cowpea, vegetable soybean, etc.) are consumed as vegetables, while for most others the mature grains are either consumed as such, or as sprouts or in various processed products. The fast growth and quick time-to-harvest of vegetables and legumes and their ability to yield in normally fallow periods not only improves soil-protective land cover, but also helps break pest, disease, and weed cycles in cereal-dominated cropping systems.

The ability of legumes to fix nitrogen and improve soil health enhances farm productivity and smallholder incomes, while reducing the high costs of production incurred through exogenous application of inorganic fertilizers. The fixed nitrogen is gradually released from decaying root, leaf, and shoot biomass, thereby improving soil fertility, organic matter status, and making some nitrogen available for subsequent crops (or intercrops), mostly cereals (Crews \& Peoples, 2005). Subsequent cereal crops will not only give higher grain yields for human consumption but also higher stover yields that can be used for livestock feed. Legume haulms are nutritionally rich as livestock feed, improving milk let-down, and meat quality in crop-livestock systems. The livestock manure may also go back to the crop production fields to improve soil structure and fertility, thus ensuring sustainable land resource management. Such an interaction enhances the productivity of staple crops with reduced inputs, and includes vegetables, legumes, meat, and milk that together are an effectively balanced diet.

Throughout Africa, rice is usually produced as a single crop each year under rain-fed conditions with a production cycle of between 3 and 6 months. Irrigation provides opportunities to increase the potential yields of upland rice during the major production season while promoting diversification with vegetable and legume crops in the off-season period by making use of residual water following the harvesting of the main rice crop. In the past, many paddy fields were left fallow during the 5- to 6-month off-season period despite the availability of water. This is changing with the introduction of chickpea, mungbean, and vegetables in rotation with rice. Field research data have shown increases in rice yields by more than $1 \mathrm{t} /$ ha when grown in rotation with vegetables and legumes. Vegetables and legumes help to diversify risks in the farming portfolio because of their higher farm gate values and ability to utilize residual moisture from the previous rice crop. It is estimated that growing rice with vegetables and legumes in rotation could procure average profit margins of USD 172/ha against USD 110/ha for rice alone (Agrifood Consulting International, 2005).

\section{Nutritional Security Through Consumption of Vegetables and Legumes}

Micronutrient deficiencies, including lack of vitamin A, iron, zinc, and iodine, are among the most devastating problems facing the majority of the poor and 
needy in sub-Saharan Africa. For example, vitamin A deficiency suppresses the immune system, increasing the risk of childhood mortality from infectious diseases (World Health Organization, 1995). It causes night blindness estimated to affect 5.2 million preschool-age children ( 0.9 percent of the population at risk) and 9.8 million pregnant women (7.8 percent of the population at risk), of whom the majority are found in sub-Saharan Africa and Southeast Asia (http://www. who.int/vmnis/database/vitamina/x/en/). Furthermore, an estimated 250,000 500,000 vitamin A deficient children become blind every year, half of them dying within 12 months of losing their sight (World Health Organization, 2013). Worldwide, an estimated 250 million preschool children are vitamin A deficient and it is likely that in vitamin A deficient areas a substantial proportion of pregnant women also suffer from the lack of this essential nutrient. In the 38 countries of sub-Saharan Africa, vitamin A deficiency causes an estimated 578,000 child and 32,000 maternal deaths annually (http://www.micronutrient. org/resources/publications/1665-3pannel.pdf).

Inadequate intake of iron and zinc is another widespread problem in subSaharan Africa. The groups most affected by anemia are adolescent girls, women of childbearing age, and preschool children. Iron-deficiency anemia is linked to learning disabilities, mental retardation, poor physical development, and a reduced ability to fight infectious diseases, ultimately leading to premature death. This deficiency diminishes the stamina and work capacity of adults by as much as 10-15 percent, and it is estimated that it results in losses in gross domestic product of up to 1.5 percent, thus, exerting a high economic burden on society (World Health Organization, 2002). A micronutrient-deficient society is an unhealthy one, and an ailing society is unlikely to be able to produce sufficient food to feed itself. The most sustainable way to tackle food insecurity is through tackling nutritional insecurity, thereby improving the health and productivity of the populace.

Some approaches suggested to address micronutrient deficiencies include supplementation with vitamins and minerals in capsules, tablets, and syrups; fortification of staple foods; and diet education on micronutrient-rich foods (Vitamin and Mineral Deficiency Report, 2008). Supplementation is common in developed countries and among the affluent populations in developing countries. The approach is effective and can be used in developing countries but at a relatively high cost. Food fortification is done during processing by adding essential vitamins and minerals to foods that are regularly consumed by a significant proportion of the population such as sugar (as done in Latin America), salt (iodized salt to control iodine deficiency diseases such as goiter), oil, milk, margarine, infant foods, and various types of flour (Hughes \& Keatinge, 2012).

Biofortification, which involves enhancing the micronutrient content, mostly of staple food crops using conventional and biotechnology-aided techniques, is increasingly becoming an important process in fighting nutrition insecurity. The approach takes advantage of the fact that the target populations, mostly the poor households, will consistently consume large amounts of the target staple food. Therefore even a modest increase in the content of a particular micronutrient in 
these staples is assumed to make a significant contribution in tackling the deficiency of the micronutrient. Besides, while commercially fortified foods may be available in different formulations in towns, biofortified staple foods are expected to reach the poor undernourished rural populations both in towns and rural areas much more readily. Improving varieties for micronutrient density does not inflict a yield penalty on the varieties (Penelope, Bouis, Meenakshi, \& Pfeiffer, 2006). Rather, microelement-dense varieties may express better seedling survival, seedling vigor, disease/pest resistance, environmental stress tolerance, and ultimately higher yields.

Quality Protein Maize (QPM) hybrids and varieties with increased levels of protein and acceptable texture and taste bred by the International Center for Maize and Wheat Improvement (CIMMYT) have been released in many parts of Africa (Pray, Paarlberg, \& Unnevehr, 2007). Orange-fleshed sweet potato with high pro-vitamin A content developed by the International Potato Center (CIP) has contributed to reduction in vitamin A deficiency in healthy children by 24 percent in Mozambique (Pray et al., 2007). Other examples include "Golden Rice" containing $\beta$-carotene, for which research is underway to stack other nutritional traits; potato containing additional protein; cassava with increased iron, zinc, and vitamins $\mathrm{A}$ and $\mathrm{E}$; sorghum containing pro-vitamin A, vitamin $\mathrm{E}$, iron, zinc, and amino acids (Bouis, Hotz, McClafferty, Meenakshi, \& Pfeiffer, 2011); and high-b-carotene tomato varieties (Ali \& Tsou, 2000).

Among the legumes, common bean with high iron and zinc has been developed by the International Center for Tropical Agriculture (CIAT) and is being promoted in Rwanda and Democratic Republic of Congo (Bouis et al., 2011). AVRDC is exploring potentials for biofortifying mung bean with possible target areas being iron, zinc, and essential amino acids (Nair et al., 2013). ICRISAT is putting up new initiatives to biofortify groundnuts, chickpea, and pigeonpea. The protein content of currently available varieties of chickpea and pigeonpea generally ranges between 20 and 22 percent. Germplasm lines with high protein content ( $>28$ percent) have been identified in each of these legumes. These can be exploited for development of high protein varieties. An improvement in the protein content by 20-25 percent appears feasible and high-protein chickpea and pigeonpea cultivars will improve protein availability to the people by $20-25$ percent from the same amount of these legumes consumed. Protein and oil content and oil quality as determined by variation in ratio of oleic $(\mathrm{O})$ and linoleic (L) fatty acids are important seed quality traits of groundnuts. Natural variation for these traits have been reported in germplasm and research to date suggests that these traits could be improved through genetic means. Some progress has already been achieved at ICRISAT toward developing varieties with high oil (up to 55 percent) and improved oil quality (O/L ratio 3:1) (Mukri et al., 2012). Pigeonpea accessions with $>60 \mathrm{ppm}$ Fe and $>70 \mathrm{ppm} \mathrm{Zn}$ and groundnut accessions with high Fe (up to $50 \mathrm{mg} \mathrm{kg}-1$ ) and $\mathrm{Zn}$ (up to $80 \mathrm{mg} \mathrm{kg-1}$ ) have been identified. Significant progress has been made in genetic enhancement of these traits following conventional breeding in sorghum and pearl millet. However, such efforts need to be initiated in chickpea, pigeonpea, and groundnut. Chickpea 
contains good amounts of carotenoids $(1.6 \mu \mathrm{g} / \mathrm{g}$ seed weight) such as $\beta$-carotene, cryptoxanthin, lutein, and zeaxanthin (Jukanti, Gaur, Gowda, \& Chibbar, 2012). There is a need to further assess genetic variability in the germplasm of cultivated and wild species of chickpea for improving levels of $B$-carotene in the existing cultivars.

Some of the approaches described above may be expensive and may target only one or a few nutritional factors, with potentially significant cost implications. Vegetables such as amaranth, African eggplant, African nightshade, Ethiopian mustard, moringa, and jute mallow are rich in pro-vitamin $\mathrm{A}$ and vitamin $\mathrm{C}$, several mineral micronutrients, health-promoting phytochemicals with antioxidant, antibiotic and anticancer properties, and other nutraceuticals (Yang, Fischer, Hanson, \& Keatinge, 2013). Legumes, such as chickpea, groundnuts, pigeonpea, mungbean, soybean, and common bean, among others, are rich in protein, oil, minerals ( $\mathrm{P}, \mathrm{Ca}, \mathrm{K}, \mathrm{Mg}, \mathrm{Fe}, \mathrm{Zn}, \mathrm{Cu}, \mathrm{Mn}$, and Se), vitamins (B1, B2, B3, B5, B6, choline, E, and folate), phenolic compounds, and fiber. For example, raw chickpea seeds $(100 \mathrm{~g}$ ) on average provide about $5 \mathrm{mg} / 100 \mathrm{~g}$ of $\mathrm{Fe}, 4 \mathrm{mg} / 100 \mathrm{~g}$ of $\mathrm{Zn}$, $138 \mathrm{mg} / 100 \mathrm{~g}$ of $\mathrm{Mg}$, and $160 \mathrm{mg} / 100 \mathrm{~g}$ of Ca. About $100 \mathrm{~g}$ of chickpea seeds can meet the daily dietary requirements of $\mathrm{Fe}(1.05 \mathrm{mg} / \mathrm{d}$ in males and $1.46 \mathrm{mg} / \mathrm{d}$ in females) and $\mathrm{Zn}(4.2 \mathrm{mg} / \mathrm{d}$ in males and $3.0 \mathrm{mg} / \mathrm{d}$ in females) and $200 \mathrm{~g}$ can meet that of $\mathrm{Mg}(260 \mathrm{mg} / \mathrm{d}$ in males and $220 \mathrm{mg} / \mathrm{d}$ in females). Additionally, the total dietary fiber content in chickpea is $18-22 \mathrm{~g} / 100 \mathrm{~g}$ of raw chickpea seed, which is the highest among legumes (Jukanti et al., 2012).

There is an upsurge of chickpea consumption in vegetable green pea form in producing countries in sub-Saharan Africa, which should be promoted through the development of early maturing sweet-tasting varieties. Besides, consumption of chickpea and other legumes in sprouts is gaining in popularity. Already this is well established for soybeans. Sprouting of grains for a limited period increases activities of hydrolytic enzymes, improvement in the contents of certain essential amino acids, total sugars, and B-group vitamins, and decreases the dry matter and starch content, thereby improving the quality and palatability. The digestibility of storage proteins and starch are improved due to their partial hydrolysis during sprouting. Removal of seed coat in chickpea and pigeonpea through dehulling and production of chickpea splits (dal) is one traditional way to improve the cooking time. The cotyledons are attached tightly with seed coat by various gums; dehulling involves dissolving the gum layers by soaking whole seeds in water, providing a heat treatment, or adding oil after surface scarification. This is followed by drying, dehusking, and splitting of cotyledons. Processed chickpea/pigeonpea dal takes less time and is more nutritious.

Food systems of many poor sub-Saharan Africa households include legumes or vegetables as accompaniments to starch-based staples, which are less palatable without these relishes. For example, chickpea is mainly eaten in Ethiopia in the form of "shiro," a homogenous stew that accompanies "injera," a sourdough flatbread with a slightly spongy texture eaten by all households and nearly during all meals. Similarly, groundnuts soup in Uganda is the main accompaniment of "matoke" (banana and plantain) staples. Chickpea, pigeonpea, common 
bean, cowpea, and groundnuts are mixed in various proportions with maize to form "githeri," a delicacy in many rural homes in Eastern, Southern, and parts of Central Africa. In Tanzania, every meal is invariably accompanied with a dish of common bean stew.

While these relishes are already available to households in various proportions, inclusion of legume powder or paste in conventional cereal-based products such as snacks, curry, enriched bread powder, weaning foods, baked and extruded products, flakes, and pops are initiatives to enrich the micronutrientdense food intake of vulnerable groups. These products contribute to nutrition and market values of the staples. While consumption of some of the conventional products is already high, especially among urban populations, incorporating legumes such as chickpea, pigeonpea, mungbean, and groundnut in the products is one sure way to enhance the consumption of these micronutrient dense pulses to diversify and complement their "junk food" diets. Increased consumption is aimed at addressing hidden hunger of the vulnerable group, as well as demand for the pulses, thus, improving the income of farmers.

Innovative cooking approaches and recipes that enhance bioavailability of various micronutrients and retention of vitamins are critical especially for vegetables in which cooked products may be significantly different from raw ones in terms of nutrient profile. Several studies showed that cooking vegetable mixtures from either two of African nightshade (Solanum scabrum), amaranth (Amaranthus blitum), slenderleaf (Crotalaria ochroleuca), sweet potato leaves (Ipomea batata), and cowpea leaves (Vigna unguiculata) together increased iron bioavailability when compared to cooking one vegetable. Frying these vegetables increases iron content compared to boiled ones and raw vegetables. In vitro simulated gastrointestinal digestion of African nightshade revealed that the accessibilities of iron, carotenoids, and flavonoids are improved more in the cooked leafy vegetables than raw, oven dried, and sun dried samples (Oluoch, Habwe, Ngegba, Koskei, \& Yang, 2012). Besides enhancing micronutrient bioavailability and vitamin retention, improved recipe formulation may enhance vegetable taste, acceptability, and consumption and thus increase micronutrient and vitamin intake (Yang et al., 2013).

The World Health Organization of the United Nations encourages "ready-touse therapeutic foods" (RUTF) for community-based treatment of severe malnutrition. These include Plumpy'nut ${ }^{\mathbb{R}}$, which contains the right mix of nutrients to treat a child with severe acute malnutrition. Groundnuts are a good source of biologically active compounds (arginine, resveratrol, phytosterols, and flavonoids), and is the main ingredient in Plumpy'nut. Plumpy'nut formulations are (i) calorie-dense, high in proteins, vitamins, and minerals; (ii) simple to deliver and administer without training (parents can deliver it to a child); (iii) fast acting; (iv) affordable; (v) culturally acceptable; (vi) packed in single-serve packets (with a fixed amount of calories); (vii) requiring of little preparation before use; (vii) equipped with adequate shelf-life and stability; (ix) able to be stored in varied climatic conditions and temperature; $(\mathrm{x})$ resistant to bacterial contamination; and (xi) not causative of addiction in children. 
Moringa leaves are rich in vitamins A, C, E, folates, and iron (Yang et al., 2013) and the leaf powder is sometimes added to Plumpy'nut paste (Grubben \& Denton, 2004). An intimate relationship exists between minerals, trace elements, and vitamins which, when combined in certain specific groupings, are bioavailable, inexpensive, and easily accessible (Yang et al., 2013).

\section{Income Security Through Production and Trade in Vegetables and Legumes}

Since the 1990s, the area sown with legumes globally has increased by 10 percent, yields by 12 percent, and production by 24 percent (Akibode \& Maredia, 2011), with most of this increase in sub-Saharan Africa. However, most developing countries are net importers of legumes (Akibode \& Maredia, 2011). Legume imports worldwide have been increasing since the mid-1990s, particularly by India, at a rate much exceeding the growth rate of global production. While this is a bad indicator for the importing country consuming significant amounts of its foreign exchange reserves, it is also a positive sign of a potential market for countries producing surpluses for export. For example, Ethiopia produces more chickpea than its population of nearly 95 million people can consume. Much of this chickpea is exported, mostly to India. Ethiopia accounts for more than 60 percent of Africa's global chickpea market, with the net household income from the trade estimated at USD 1,500-2,000 per hectare (Fikre, 2014).

An assessment of household participation in growing African eggplant in four villages in Tanzania's Arumeru district found significantly higher incomes and women's empowerment than in villages not growing eggplant (Tenkouano, 2011). The "DB3" eggplant (officially released in Tanzania in 2011) can be harvested every week for 7 months and can produce for up to 15 months if the plants are pruned back at the end of the growing season. A typical farmer can harvest $10-20$ bags $(30 \mathrm{~kg} / \mathrm{bag})$ of eggplant every week throughout the 7 -month growing season and earn USD 2,500 per hectare per year. Growers of African eggplant allocated more land (0.76 hectares on average) to food crops and received higher estimated annual incomes (USD 2041) than those who did not grow this crop (0.70 hectares and USD 1692). The profit margin of African eggplant (difference between purchase at farm gate and selling price as a share of selling price) is 34 percent in Benin, 44 percent in Côte d'Ivoire, 39.9 percent in Senegal, 33.8 percent in Tanzania, and 43.4 percent in Uganda (Weinberger \& Pichop, 2009).

A decade ago, African indigenous vegetables were mostly growing in the wild or were semi-cultivated. Resurgence in popularity-supported by farmer market linkages to municipal, urban, supermarkets, and hotel chains-has led to rapid domestication and commercialization of production through contracts (Abukutsa-Onyango, 2002; Ojiewo, Tenkouano, Hughes, \& Keatinge, 2013; Weinberger, Pasquini, Kasambula, \& Abukutsa-Onyango, 2011). Similarly, pigeonpea and chickpea in eastern and southern Africa, which were infamously referred to as orphaned crops, have been changing smallholder farmers' fortunes. Chickpea export from eastern Africa has substantially increased after 2001 and 
ranged between 11,000 and 122,000 tons per year. The introduction of new largeseeded kabuli cultivars in eastern Africa and linking up chickpea farmers to local and export markets have enabled them to earn extra income through export of these high-valued chickpeas. Awareness created of chickpea demand in the local and export markets have contributed to rapid adoption of new cultivars that combine early maturity and resistance to fusarium wilt in Ethiopia, Tanzania, Sudan, and Kenya, leading to an increase in area from 0.21 to 0.41 million ha, production from 0.15 to 0.37 million tons, and productivity from 0.71 to 0.90 tons / ha during the period 1978-80 to 2007-09 (http:/ /www.icrisat.org/cropchickpea.htm). Similarly, pigeonpea area increased 2.5-fold (0.23-0.82 million ha) and production by threefold (0.13-0.53 million tons) between 1976 and 2009 in Mozambique, Malawi, Tanzania, Kenya, and Uganda combined. It is also grown both for domestic and export markets (http://www.icrisat.org/crop-pigeonpea. htm).

\section{Improving Gender Roles in Vegetables and Legumes}

It is no secret that African women conspicuously contribute to food and nutrition security as producers, processors, preparers, and providers of food for their families while preserving biodiversity and associated indigenous knowledge. This is particularly true for vegetables and legumes because they are amenable to production as small-scale enterprises and can be a significant moneyearner for women with little capital, limited access to land, and working under labor constraints (Keatinge et al., 2012). In many parts of Africa, women are more visible in the production and marketing of vegetables, legumes, and small-scale processing (e.g., groundnuts for home consumption and local sale) while men tend to dominate in the marketing of cereals in the food value chain (Bationo et al., 2011). When men leave agricultural communities in search of employment opportunities in cities, women are forced to assume their tasks. Due to these increasing roles in growing and marketing of vegetables and legumes compared to staples such as rice, wheat, and maize, these crops are generally considered "women's crops" (Food and Agriculture Organization, 2007b). The cash raised from vegetable and legume sales contributes significantly to food security at the household level and enables women to attain a degree of financial independence within the family budget. Attention to the specific needs of women, and finding means to ensure that they contribute to, and benefit from, food security programs and interventions are key to supporting this process (Keatinge, 2013).

Women make significant contributions to the rural economy in all developing countries. Their roles differ across regions, yet they consistently have less access than men to resources and opportunities such as education, which they need, to be more productive. Increasing women's access to land, livestock, education, financial services, extension, technology, and rural employment would boost their productivity and generate gains in terms of agricultural production, food security, economic growth, and social welfare (Bationo et al., 2011). Closing the gender gap with respect to agricultural inputs alone could lift 100-150 million people out of 
hunger (Food and Agriculture Organization, 2011). Governments, the international community, and civil society should work together to eliminate discrimination under the law, to promote equal access to resources and opportunities, to ensure that agricultural policies and programs are gender-aware, and to make women's voices heard as equal partners for sustainable development. Achieving gender equity and empowering women in agriculture is crucial for agricultural development and food security and this is articulated clearly in the new UN Sustainable Development Goal 2. There are increasing indications that the management of vegetable and legume production and marketing is gender-based, with women predominating not only in the collection of vegetables and legumes, but also in planting fields and gardens, and in crop protection (Chweya \& Eyzaguire, 1999). A study on the gender division of labor found that indigenous vegetables in urban and peri-urban areas of sub-Saharan Africa are mainly produced by men and marketed by women, while in rural areas, women dominate both production and marketing (Pichop, 2007). The explanation given for the findings is that in order to maximize yields and returns from limited agricultural land in urban and peri-urban areas, farmers generally engage in very intensive commercial production, with more and more men getting involved. In sub-Saharan Africa, the production of major staple and cash crops is generally male-dominated, while women typically engage in subsistence production and small-scale market gardening mainly involving vegetables and legumes. As vegetable and legume production increasingly becomes a cash-generating activity, women call for the support of men. When production becomes highly commercialized, men tend to take over the value chains as is the case with common bean in the central rift valley of Ethiopia and the lowlands of northern Tanzania (Bationo et al., 2011).

In rural areas, where producing indigenous vegetables is mainly a subsistence activity, production and marketing is undertaken mainly by women. The further away from the urban setting, the more women engage in production activities, while men are called upon for tasks that require strength. In Cameroon, for example, activities such as ploughing, irrigation, and fertilizer and pesticide application are done by men, while sowing, harvesting and trading are done by women (Gockowski, Mbazo'o, Mbah, \& Moulende, 2003). An important point to note is that besides contributing to food and nutrition security and employment, vegetable and legume production empowers women and youth through income generation (Schreinemachers et al., 2014).

In order to ensure that the consumption levels of vegetables and legumes are high, gender roles are very important. Low intakes of indigenous vegetables by women and children in the wetlands of the Lake Victoria region have been reported to be partly due to bitterness (Waudo, Tuitoek, Msuya, \& Kikafunda, 2005). Some phytochemicals taste bitter, acrid, or astringent, such as bitter phenols and tannins, bitter glucosinolates in cruciferous vegetables, acrid and unguent isothiocyanates, and some other bitter toxic compounds (Drewnowski \& Gomez-Carneros, 2000). In Africa, cooking of vegetables and legumes is almost entirely done by women. Recipes that improve the palatability and bioavailability of various micronutrients or the retention of vitamins should be developed and 
women trained to use them. Women are primarily responsible for providing and preparing nutritious food for their families, thus, they hold the decision-making power on whether the family will or will not consume nutritious vegetables.

AVRDC-The World Vegetable Center is presently undertaking research to ensure that horticultural cultivation by women does not imply excessive physical drudgery to add to their existing daily workload and provides more nutritional benefit for their families. Such experiments would include the improved breeding and seed production of green leafy species with high nutrient density such as African leafy nightshade; also species such as Amaranthus, which will allow more repetitive harvests per season than existing varieties. Trickle irrigation systems with solar cell technology are being tested to reduce the need for heavy energy demanding water pumping and repetitive carrying in watering cans by women and children. Additionally, chili (Capsicum spp.) varieties are being considered, which allow easier harvesting as their fruit are borne erect on the plant. Likewise, mung bean varieties (Vigna spp.) are being introduced as they have less tendency toward pod shattering at harvest and their seeds are more resistant to storage pests such as bruchids (Bruchus spp.). Simple technologies such as brick zero energy storage chambers are being evaluated to allow harvested vegetables to better retain their moisture and nutrient content prior to cooking or waiting for transport to market. Policy issues and capacity building to allow women to more effectively participate in profitable horticulture are being developed and undertaken (AVRDC, 2014).

The ICRISAT-led CGIAR Research Program on Grain Legumes has outlined a clear and proactive gender-inclusive research strategy, which includes diagnostic research around critical gender issues to strengthen the relevance and targeting of legumes research for development for enhanced impacts, and to inform and deepen the relevance of other research themes of the program; and assessment studies that focus on analyses for the impact of gender on the outputs of the CRP and in related areas as feedback. ICRISAT, through its Inclusive Market-Oriented Development strategy mainstreams gender, positioning it within a research paradigm that is initially gender-equitable but, ultimately, gender transformational. For example, proactive inclusion of women groundnut farmers in Mali and Niger has been implemented with significant outcomes. More than 50 percent and 40 percent of the groundnut plots belong to women in Mali and Niger, respectively. Some of the challenges facing women groundnut farmers in these two countries include poor access to family labor, poor access to seed of modern varieties, poor access to fertilizers, and poor access to credit because of lack of physical or social collateral owned by women. ICRISAT-led Groundnut Seed Project (2003-07) aimed at the development of sustainable groundnut seed systems in West Africa, and the Tropical Legumes II in its Phase 1 (2008-10) aimed at enhancing legume productivity in drought-prone areas of sub-Saharan Africa and South Asia and in Phase 2 (2011-14) helped to establish linkages between the national agricultural research institutes and individual women farmers and farmers' associations as well as women's associations and rural radios to facilitate the dissemination of information on varieties and seed sold, 
the location of seed sales, and groundnut crop management techniques. Through these initiatives women were directly involved in the economic growth.

\section{Vegetable and Legume Crop Improvement Research in Sub-Saharan Africa}

For vegetable and legume production to remain a profitable business in subSaharan Africa, the need for varietal improvement to ensure resistance or tolerance to various biotic and abiotic stresses as well as good horticultural and consumer traits cannot be overemphasized. Through its current research bases in Cameroon, Mali, and Tanzania, AVRDC-The World Vegetable Center collaborates with various public and private partners including seed companies, national agricultural research and extension services (NARES), NGOs and communitybased organizations (CBOs), farmer groups, universities, and international research organizations to develop and release new varieties.

An example of these variety releases are the tomato varieties adapted to subSaharan Africa agroecologies and with horticultural traits appreciated by the African market, which were released in Tanzania in 1997. The varieties "Tanya" and "Tengeru 97" revolutionized tomato production in Tanzania, increasing production by 40 percent and increasing net income gains by 21 percent (AVRDC, 2008). These varieties have carved their own niche in the tomato market and replacing them is difficult. The two varieties dominate the markets in Tanzania, DRC Congo, Uganda, and Zambia and are also grown in Kenya, South Sudan, Malawi, and Zimbabwe. Farmers also export these tomatoes as fresh produce to Mauritius and the Middle East because of their good handling qualities and long shelf-life. Investment in quality seed of these varieties can give up to 80-fold returns in income for smallholder farmers (Tenkouano, 2011).

In recent years, AVRDC-The World Vegetable Center has refocused its efforts in developing late blight (Phytophthora infestans)-resistant tomato varieties. Late blight is a disease affecting tomato in the cool humid tropics, causing substantial losses if not controlled. Farmers in the southern highlands of Tanzania apply fungicides 20-30 times a season to control late blight during the peak tomato growing period. Use of chemicals to control late blight in tomato increases production costs by up to 20 percent (Ojiewo et al., 2010), but could be much higher with the use of increased quantities of pesticides or the substitution of more expensive fungicides to control resistant strains of late blight. With the use of new, late blight-resistant varieties "Meru" and "Kiboko," farmers in the southern highlands of Tanzania have reduced fungicide use to 6-8 times a season, mainly to control early blight (Ojiewo et al., 2010). Two new tomato varieties, "Tengeru 2010" and "Duluti," both released in 2011, have the potential to reduce fungicide applications even further as they combine late and early blight resistance.

Demand has been rising steadily for African nightshade as manifested in urban supermarkets, groceries, retail markets, and hotels, thanks to promotional activities by research institutes and NGOs in East Africa (Ojiewo, Mwai, et al., 2013). Growers traditionally obtain yields of about $3 \mathrm{t} / \mathrm{ha}-$ which is very low 
compared with potential yields of about $30 \mathrm{t} / \mathrm{ha}$. Farmers traditionally harvest African nightshade by uprooting. The traditional varieties are small, early flowering, and low yielding, especially given the single clear harvest (Ojiewo, Tenkouano, et al., 2013). After the onset of flowering and seed-set, vegetative growth is suppressed (Ojiewo, Murakami, Masuda, \& Agong, 2009); thus, farmers have no choice but to clear-harvest the crop and plant a fresh one. The practice of clear harvesting by uprooting and replanting every couple of weeks is not only labor-intensive, but also costly in terms of farm inputs. In addition, the practice results in continuous disturbance of the soil, leading to rapid degradation.

Two new varieties of African nightshade, "Nduruma" and "Olevolosi" (broad-leaved), have leaves that have been described by women farmers during participatory evaluation in various localities as softer, sweeter, and cooking in a much shorter time than local landraces (Ojiewo, Mwai, et al., 2013). The new varieties grow taller and can be harvested continually with a cumulative yield potential of about $40 \mathrm{t} /$ ha after 4-6 harvests. Continuous harvesting leaves the soil intact, involves less labor in land preparation, and is less costly in terms of farm inputs. If the farmers wish to clear harvest, the new varieties mature in only 21-28 days (Ojiewo, Mbwambo, et al., 2013). Farmers have been trained to grow these varieties and have been linked to markets; the biggest constraint has been lack of seed supply. To keep up with increases in consumption and demand, the official release and commercialization of these new varieties will improve the seed supply through more formal channels. Seeds of some of these new African nightshade lines are already being commercialized by companies in East Africa.

Similar joint research efforts by the ICRISAT, International Center for Agricultural Research in the Dry Areas (ICARDA), and the Ethiopian Institute for Agricultural Research (EIAR) have resulted in the release of more than 20 varieties of chickpea over the past 4 decades. Adoption of these varieties resulted in increased chickpea production to $322,839 \mathrm{t}$ and productivity to $1.73 \mathrm{t} /$ ha in 2012, compared to 2003-05 production and productivity levels of 168,000 t and $0.98 \mathrm{t} / \mathrm{ha}$, respectively (Fikre, 2014). The change in production is about 92 percent over 2003-05 base figures, and both gains in area (33 percent) and productivity (77 percent) have contributed to these rapid increases. The estimated level of improved chickpea variety adoption now is between 25 and 30 percent. The main drivers of adoption are (i) increased demand and prices in the export market; (ii) reduction in the production costs of the new varieties; (iii) generally lower input levels compared to other crops; (iv) soil improvement, reduced need for nitrogen fertilizer, and improved yields of subsequent crops when chickpea is used as a rotation crop; and (v) increased consumption leading to increased local demand (Shiferaw, Jones, Silim, Teklewold, \& Gwata, 2007). A recent assessment of the potential economic and poverty impact of 11 improved chickpea varieties released by EIAR in collaboration with ICRISAT estimated a total benefit of US $\$ 111$ million for 30 years. Consumers were estimated to get 39 percent of the benefit and producers 61 percent. The benefit/cost ratio was estimated at 5:1 and an internal rate of return of 55 percent, indicating that investment in chickpea variety development and dissemination is highly profitable. The generated benefit 
was estimated to lift more than 0.7 million producers and consumers out of poverty (Macharia, Orr, Simtowe, \& Asfaw, 2012).

Long-term collaborative pigeonpea research for development efforts among ICRISAT, National Agricultural Research and Extension Systems (NARES), private sector, extension staff, and farmer groups in Tanzania has resulted in an increased production area from 60,000 in 1995 to 290,000 ha (about 380 percent) and productivity from 0.5 to $0.95 \mathrm{t} /$ ha (about 90 percent) in 2011. The varieties developed and disseminated through this collaboration have contributed to increased production, higher farmers' income, increased utilization, and improved livelihoods. In the Babati district of Tanzania adoption of improved varieties has reached 80 percent, and pigeonpea alone contributes more than 50 percent of the cash incomes for smallholder farmers. Arumeru, Babati, Karatu, and Kondoa districts in Tanzania are known for their production of bold creamcolored pigeonpea derived from these collaborative research efforts. In Malawi, seven pigeonpea varieties (two short-duration types: ICPL 87105 and ICPL 93027; three medium-duration varieties, "Mwaiwathu alimi," "Chitedze pigeonpea 1," and "Chitedze pigeonpea 2"; and two long-duration varieties, "Sauma" and "Kachangu") have been released and adopted. There are prospects of extending the cropping area to central and northern Malawi due to release of mediumduration varieties (ICEAP 00557 and ICEAP 01514/15). During the last 18 years, the area of pigeonpea has increased from 97,000 in 1995 to 203,400 ha (about 110 percent) and productivity from 0.54 to $1.17 \mathrm{t} /$ ha (about 117 percent) in 2012, with the increase in the adoption of high-yielding varieties.

Mungbean (green gram) is slowly but steadily expanding in sub-Saharan Africa. It is an important crop in the warm dry regions of eastern Kenya, grown both for subsistence and a cash crop (Shakoor, Rono, \& Ngugi, 1984). Dry grain is used as food; the Asian community, currently the largest consumer of the crop, cooks it as split grains for dhal. During 2003-06, mungbean production in Kenya increased from $26,147 \mathrm{t}$ to $43,339 \mathrm{t}$, amounting to about a 65 percent increase. The national yield also rose from $0.36 \mathrm{t} /$ ha to $0.45 \mathrm{t} /$ ha representing a 25 percent increase. This increase in mungbean production can be attributed partly to the use of improved technologies and partly to expansion of production area due to increasing climatic uncertainty. Rainfall has recently become erratic in East Africa, even in high potential areas, leading to poor crop yields due to moisture stress. This has forced farmers in such areas to change to drought-tolerant, shortduration crops like mungbean, thus leading to an expansion of the area under this crop (Rael Karimi, personal communication). Most farmers grow local varieties that are low yielding and late maturing (about 90 days). The recent introduction of early maturing mungbean lines (60 days) from AVRDC is showing good promise of acceptance among farmers. A farmer participatory variety selection conducted recently in Katumani in Kenya showed that a high yielding, early maturing, large seeded mungbean variety with shiny green colored seed will likely have an immediate high adoption rate (Rael Karimi, personal communication). In Tanzania, the mungbean area increased from 3,000 ha in 2005 to 6,000 ha in 2010 . Average yield levels of about $900 \mathrm{~kg} / \mathrm{ha}$ have 
been maintained during the same period (http://www.kilimo.go.tz/agricultural $\%$ 20statistics/angricultural\%20statistics.htm).

\section{Participatory Approach in Product Development}

A common approach used to promote new varieties is to plant several advanced lines alongside standard varieties in farmers' fields; stakeholders jointly participate in selecting the best-bet variety based on agreed criteria and priority traits. Thus researchers consult with farmers who advise about the varieties best suited to their particular needs. This can be done through workshops, conferences, and field days bringing together farmers, consumers, businesses, and the surrounding communities (Tenkouano, 2011). End-user driven varietal development approaches have been used to promote vegetable and legume varieties. Inclusion of women in bean variety development through participatory variety evaluation and selection led to faster identification and adoption of improved bean varieties suited to small production niches in Rwanda (Sperling, Loevinsohn, \& Ntabomvura, 1993).

To ensure that increased demand for seeds due to farmers' awareness of new varieties is met, research agencies must work with established institutions and private sector seed companies. These companies can evaluate and start growing the varieties chosen by farmers on their own farms. In this way, the farmers' decisions about the best varieties are communicated directly to seed producers and they, in turn, can respond to the demand. The companies can also start doing the research necessary to make sure the new varieties meet regulatory requirements for seed production and certification.

The engagement of farmers, national programs, processing industries, and private seed companies enhances sustainability and the adoption of new improved varieties. In Ethiopia, improved varieties of chickpea have been brought to farmers' doorsteps by conducting hundreds of on-farm participatory variety selection trials based on agronomic traits and market preferences, followed by large-scale demonstrations involving a selected few varieties.

\section{Seed Systems for Vegetable and Legume Production and Productivity}

The official variety release and certification system in most African countries is very lengthy, tedious, and expensive, thus encouraging imports of varieties often not adapted to local conditions. The need for better seed laws that encourage production and distribution of high quality seed of improved varieties at affordable costs cannot be overemphasized. The position of the African Seed Trade Association (AFSTA) is that vegetable seeds should not be subject to mandatory certification in Africa; rather, the seed should be traded under the label of "standard seed" or "truthfully labeled seed" as practiced in Europe, America, and Asia (African Seed Trade Association, 2007). In addition, policyrelated constraints limit the private sector's access to foundation seeds-the 
approved seeds formally available for seed production-from the seriously underfunded public sector.

Quality seed production requires mastery of both the technical knowledge of seed biology (including the skills to overcome any biological restrictions) and the managerial skills to run a seed business. Training seed company personnel in these often-overlooked skills, as well as developing better systems for seed drying and packaging, can make a huge difference in both the quality and quantity of local seed that is sold. Seed suppliers in Tanzania, for example, have worked with AVRDC to learn about better methods for preserving seeds, better packaging, and truthful labeling with appropriate information for the farmers (Tenkouano, 2011).

Although not perceived as profitable by large multinational seed companies, open-pollinated vegetable and legume varieties continue to be widely planted by farmers in sub-Saharan Africa (Afari-Sefa, Tenkouano, Ojiewo, Keatinge, \& Hughes, 2012). Unlike hybrid seeds, they do not need to be purchased every planting season as seed can be saved by the farmer, and the open-pollinated seeds are far less expensive to buy. In most cases hybrid vegetable seeds are still too expensive for most smallholder farmers. They are also typically bred for higher-input agricultural systems and thus often fail to thrive with the lower inputs used by small-scale farmers. Currently, there are no legume hybrids being produced at a commercial scale anywhere in Africa. The first known legume hybrids are in pigeonpea. These are being promoted in India, but their adaptation and adoption in Africa is still at the rudimentary research stage. Thus, it is essential that smaller domestic seed companies continue to recognize the market for open-pollinated varieties and to stimulate, and meet, demand from farmers.

Developing innovative strategies that bring farmers, researchers, and seed dealers together will go a long way toward strengthening vegetable and legume seed systems in Africa and also ensure easy access by farmers to locally adapted and affordable seed. In Ethiopia, for example, access to quality seed has for a long time remained a hurdle for quick dissemination of promising chickpea varieties. However, strategic partnerships between ICRISAT, ICARDA, and national and regional seed enterprises (Ethiopian Seed Enterprise-ESE, Oromia Seed Enterprise-OSE, Amhara Seed Enterprises-ASE), NGOs (World Vision, CARE, Catholic Relief Services, TechnoServe), seed growing associations of revolving seed schemes (Lemelem Chefe, Hawiboru, Biftu, Chala, Megeretu Denkaka, Ude, Memerhager), and emerging private seed companies have helped to step up seed availability. Similarly, regular discussions and common platforms with ICRISAT's strategic partners including NARES, private seed companies, NGOs, grain traders, input suppliers, and farmer associations in production and marketing have led to improved access to legume seed. Through such partnerships, farmers and extension agents have been trained in legume seed production, storage, processing, and marketing.

One example of a successful strategy for legume seed dissemination was the promotion of mini-packs of improved seeds, which ensured continuous supply and access to seeds by smallholder farmers. The use of mini-packs is based on the 
premise that farmers want access to new improved varieties but may not be able to afford the seed if packed in large quantities; farmers who cannot afford large packs are actually willing to pay for high quality certified seed at affordable sizes. The mini-packs approach ensures seed is marketed in affordable package sizes, at accessible places, and by trustworthy or responsible local vendors who may be held accountable in case of compromised quality. Adopted by a project-Tropical Legumes 2 (TL II) - the approach has helped speed up dissemination of common bean, cowpea, chickpea, pigeonpea, groundnut, and soybean varieties in Eastern and Southern Africa. The private-sector players, especially emerging small seed companies, retailers and agro-dealers, have enthusiastically embraced this approach. The TLII and its partners distributed over 1 million small seed packs to smallholder farmers through seed retail outlets during 2012-13.

\section{Lessons, Challenges, and Prospects}

While episodes of severe hunger, such as drought emergencies, receive immediate attention, chronic malnutrition poses a silent and relentless obstacle to economic development in the region. Nutrition interventions aimed at mothers and children together with programs to boost agriculture have a great impact on household nutrition and health (COHA Report, 2013). Evidence-based awareness creation and a strong multistakeholder advocacy for consumption of nutrientdense vegetables and legumes as cereal accompaniments would have a very strong impact especially in the rural areas. This comes with the challenge of demand exceeding the supply of these nutritious foods.

Some of the constraints in the production and supply chains of vegetables and legumes include limited availability of quality seeds, inappropriate varieties, lack of water and inputs, pests and diseases, limited information and knowledge, and inadequate marketing systems, among other factors (Tschirley, Muendo, \& Weber, 2004). These constraints should be tackled through well-coordinated multistakeholder and multidisciplinary research as is taking shape through the reformed CGIAR Research Programs.

Postharvest and processing losses are very important, affecting both the quantity and quality of vegetable and legumes produced in sub-Saharan Africa. As most of the micronutrients in vegetables (especially vitamins) are heatsensitive and are easily oxidized thus reducing their bioavailability (Palermo, Pellegrini, \& Fogliano, 2014), the main methods of cooking African vegetables, which involve boiling or wet heating, contribute to nutrient loss. Improper production and postharvest handling of vegetables and legumes can reduce their nutritional content and compromise food safety.

It is evident that present research practices in horticulture may be unfavorably biased against women and smallholders. Such research may often cater more for farmers with higher levels of education and who have better resources to invest in good quality inputs and more resilience in the face of experimental failure. This need not be the case, and AVRDC's and ICRISAT's research, which is encouraging the use of home gardens by women and disadvantaged groups to 
produce a wide diversity of nourishing vegetables and legumes year-round contrasts in this way with research that seeks to promote commercial monocropping and export markets (Keatinge et al., 2012; Woltering et al., 2011).

There are many opportunities, interventions, and technologies that can support vegetable and legume production and consumption, thus contributing to nutritional security. In the context of high-value crops, capacity building and policy interventions are critical to ensure mechanisms are in place to support both the production and the market, thus contributing to availability of affordable and health-promoting vegetables and legumes in sub-Saharan Africa.

Chris Ojiewo got his Ph.D. in Plant Breeding from Okayama University, Japan. $\mathrm{He}$ is currently a senior scientist at ICRISAT-Ethiopia where he is conducting crop improvement research on legumes with emphasis on chickpea.

Dyno (J. D. H.) Keatinge has a Ph.D. in Agronomy from Queens University Belfast, Northern Ireland. He is currently Director General of AVRDC-The World Vegetable Center, which seeks to alleviate poverty and malnutrition in the developing world.

Jacqueline Hughes has a Ph.D. in Virology from the University of Reading, UK. She is currently Deputy Director General Research at AVRDC-The World Vegetable Center, which seeks to alleviate poverty and malnutrition in the developing world.

Abdou Tenkouano got his Ph.D. in Genetics and Plant Breeding from Texas A\&M. He is currently AVRDC Regional Director for West and Central Africa, where he is responsible for leading the Regional Center's operations and developing its national and international partnerships.

Rajeev Kumar Varshney obtained his Ph.D. in Agriculture from Chaudhary Charan Singh University, India. He is currently director of the Grain Legumes Program at ICRISAT, where he leads a team of scientists working on various aspects of legume crop improvement along the value chain. He is also director of the Center of Excellence in Genomics at ICRISAT, where he leads genomic and molecular breeding research scientists in high-end scientific research on both legumes and cereals.

Moses Siambi got his Ph.D. in Agronomy from Iowa State University. He is currently ICRISAT's Director for Eastern and Southern Africa, where he is responsible for leading the institute's operations and developing its national and international partnerships.

Emmanuel Sifueli Monyo got his Ph.D. in Genetics and Plant Breeding from Purdue University. He is currently Principal Scientist-Breeding and Coordinator of the Tropical Legumes III project, with a major focus on leveraging partnerships, enhancing legumes productivity, and genetic gain.

NVPR Ganga-Rao got his Ph.D. in Genetics \& Plant Breeding from Indian Agricultural Research Institute India. He is currently a senior scientist at ICRISATNairobi where he is conducting crop improvement research on legumes with emphasis on pigeonpea. 
Said Silim (Ph.D. Crop Physiology, MSc Vegetable Breeding). He is currently Coordinator ICARDA Sub-Saharan African Regional Program, Addis Ababa Ethiopia. He has 37 years of research on grain legume improvement, participatory on-farm evaluation, and seed systems.

\section{Notes}

Conflicts of interest: None declared.

Corresponding author: Chris Ojiewo, c.ojiewo@cgiar.org

\section{References}

Abukutsa-Onyango, M. O. 2002. "Market Survey on African Indigenous Vegetables in Western Kenya." In Proceedings of the Second Horticulture Seminar on Sustainable Horticultural Production in the Tropics, eds. John M. Wesonga, Turoop Losenge, and Cirus K. Ndung'u October 6th-9th August 2002. Juja, Kenya: Jomo Kenyatta University of Agriculture and Technology, JKUAT, 39-46.

Afari-Sefa, Victor, Abdou Tenkouano, Chris O. Ojiewo, J. D. H. Keatinge, and Jackie d'Arros Hughes. 2012. "Vegetable Breeding in Africa: Constraints, Complexity and Contributions Toward Achieving Food and Nutritional Security." Food Security 4 (1): 115-27.

African Seed Trade Association. 2007. "AFSTA Position Paper on Vegetable Seed Regulations." http://afsta.org/wp-content/uploads/documents/IMPROVED\%20POSITION\%20PAPER\%20ON\% 20VEGETABLE\%20SEED\%20REGULATIONS\%20MARCH\%202007.pdf Accessed August 1, 2014.

Agrifood Consulting International. 2005. "Development Strategy for the Rice Sector in Mozambique." Final Report prepared for the Co-operazione Italiana, Maputo, Mozambique. http://www. agrifoodconsulting.com/./MOZ\%20Rice/MOZ\%20Rice\%20Trade\%20Report-Final.pdf. Accessed August 1, 2014.

Akibode, Sitou, and Mywish Maredia. 2011. "Global and Regional Trends in Production, Trade and Consumption of Food Legume Crops." Report Submitted to CGIAR Special Panel on Impact Assessment, p. 83. http://impact.cgiar.org/sites/default/files/images/Legumetrendsv2.pdf. Accessed August 1, 2014.

Ali, Mubarik, and Samson Tsou. 2000. “The Integrated Research Approach of the Asian Vegetable Research and Development Center (AVRDC) to Enhance Micronutrient Availability." Food and Nutrition Bulletin 21 (4): 472-81.

AVRDC-The World Vegetable Center. 2008. “New Vegetable Varieties Bring Positive Change to a Country and a Continent." Partnerships for a Better African Tomato. Point of Impact. Shanhua, Taiwan: Author.

- 2014. 2014-2016 Medium-Term Plan. Publication 14-776. Shanhua, Taiwan: Author.

Bationo, Andre, Boaz Waswa, Jeremia M. Okeyo, Freda Maina, Job Kihara, and Uzo Mokwunye. 2011. Fighting Poverty in Sub-Saharan Africa: The Multiple Roles of Legumes in Integrated Soil Fertility Management. Amsterdam: Springer.

Bellete, Solomon. 2005. "The Basic Causes of Malnutrition in Ethiopia." In An Assessment of the Causes of Malnutrition in Ethiopia. A Contribution to the Formulation of a National Nutrition Strategy for Ethiopia, ed. Todd Benson. Washington, DC: International Food Policy Research Institute, 213.

Bouis, Howarth, Christine Hotz, Bonnie McClafferty, J. V. Meenakshi, and Wolfgang H. Pfeiffer. 2011. "Biofortification: A New Tool to Reduce Micronutrient Malnutrition." Food and Nutrition Bulletin 32 (S1): 31-40. 
Chweya, James A., and Pablo B. Eyzaguire. 1999. The Biodiversity of Traditional Leafy Vegetables. Rome, Italy: IPGRI.

COHA Report. 2013. The Cost of Hunger in Africa Report: The Cost of Hunger in Ethiopia. Implications for the Growth and Transformation of Ethiopia. The Social and Economic Impact of Child Undernutrition in Ethiopia. African Union Commission, NEPAD Planning and Coordinating Agency, UN Economic Commission for Africa, and UN World Food Programme. Addis Ababa, Ethiopia: UNECA.

Crews, Timothy E., and Mark B. Peoples. 2005. "Can the Synchrony of Nitrogen Supply and Crop Demand be Improved in Legume and Fertilizer-based Agroecosystems? A Review." Nutrient Cycling Agroecosystems 72: 101-20.

Drewnowski, Adam, and Carmen Gomez-Carneros. 2000. “Bitter Taste, Phytonutrients, and the Consumer: A Review." American Journal of Clinical Nutrition 72: 1424-35.

Fikre, Asnake. 2014. "An Overview of Chickpea Improvement Research Program in Ethiopia." The Journal of International Legume Society 3: 47-49.

Food and Agriculture Organization. 2007a. Teaching Good Eating Habits to Reduce Malnutrition and Dietrelated Diseases. Rome, Italy: Author. http://www.fao.org/newsroom/en/news/2007/1000673/ index.html. Accessed Aug 2, 2014.

- 2007b. Gender and Food Security. Synthesis Report of Regional Documents: Africa, Asia and Pacific, Europe, Near East, Latin America. Rome, Italy: Author.

- 2011. The State of Food and Agriculture. Women in Agriculture: Closing the gender gap for development. Rome, Italy: Author. http://www.fao.org/docrep/013/i2050e/i2050e.pdf. Accessed August 1, 2014.

- 2013. The State of Food Insecurity in the World 2013. The Multiple Dimensions of Food Security. Rome, Italy: Author.

Gockowski, James, Julie Mbazo'o, Glory Mbah, and Terese F. Moulende. 2003. “African Traditional Leafy Vegetables and the Urban and Peri-urban Poor." Food Policy 28 (3): 221-35.

Grubben, Gerard, and Olanrewaju A. Denton. 2004. Plant Resources of Tropical Africa 2. Vegetables. Wageningen, Netherlands: PROTA.

Hughes, Jacqueline d'A, and Dyno J. D. H. Keatinge. 2012. "The Nourished Millennium-How Vegetables Put Global Goals in Reach." In Proceedings of the Regional Symposium on High Value Vegetables in Southeast Asia: Production, Supply and Demand (SEAVEG 2012). AVRDC - The World Vegetable Center, Publication No. 12-758. Shanhua, Taiwan: AVRDC-The World Vegetable Center.

Jukanti, Aravind K., Pooran M. Gaur, Laxmipathi C. L. Gowda, and Ravindra N. Chibbar. 2012. "Nutritional Quality and Health Benefits of Chickpea (Cicer Arietinum L.): A Review." British Journal of Nutrition 108: S11-26.

Keatinge, J. D. H. Dyno. 2013. "Horticulture-For Nourishing Families, Empowering Women and Commercializing Smallholders." Agriculture for Development 19: 4-7.

Keatinge, John D. H., Madan L. Chadha, Jacqueline d'A. Hughes, Warwick J. Easdown, Robert J. Holmer, Abdou Tenkouano, Ray-Yu Yang, et al. 2012. "Vegetable Gardens and their Impact on the Attainment of the Millennium Development Goals." Biological Agriculture and Horticulture 28: 71-85.

Macharia, Ibrahim, Alastair Orr, Solomon Asfaw, and Franklin Simtowe. 2012. "Potential Economic and Poverty Impact of Improved Chickpea Technologies in Ethiopia." Presented at International Association of Agricultural Economists (IAAE) Triennial Conference, Foz do Iguaçu, Brazil 18-24 August, 2012.

Mukri, Ganapati, Hajisaheb L. Nadaf, Ramesh S. B. Hat, M. V. C. Gowda, Hari D. Upadhyaya, and V. S Ujay. 2012. "Phenotypic and Molecular Dissection of ICRISAT Mini Core Collection of Peanut (Arachis Hypogaea L.) for High Oleic Acid." Plant Breeding 131 (3): 418-22.

Nair, Ramakrishnan M., Ray-Yu Yang, Warwick J. Easdown, Dil Thavarajah, Pushparajah Thavarajah, Jacqueline d'A Hughes, and J. D. H. Dyno Keatinge. 2013. “Biofortification of mungbean (Vigna radiata) as a Whole Food to Enhance Human Health." Journal of the Science of Food and Agriculture 93: 1805-13. 
Ojiewo, Chris O., Omary Mbwambo, Ignas Swai, Silvester Samali, Mansuet S. Tilya, Ruth N. Mnzava, Leon Mrosso, Ruth Minja, and Mel O. Oluoch. 2013. "Selection, Evaluation and Release of Varieties from Genetically Diverse African Nightshade Germplasm." International Journal of Plant Breeding 7: 76-89.

Ojiewo, Chris O., Kenji Murakami, Masaharu Masuda, and Stephen G. Agong. 2009. “Induced Malesterility Alters Dry Matter Distribution in African Nightshade." Acta Horticulturae 806: 571-78.

Ojiewo, Chris O., Gerald N. Mwai, Mary O. Abukutsa-Onyango, Stephen G. Aging, and Remi NonoWomdim. 2013. "Exploiting the Genetic Diversity of Vegetable African Nightshades." Bioremediation, Biodiversity and Bioavailability 7 (1): 6-13.

Ojiewo, Chris O., Ignas Swai, Mel O. Oluoch, Drissa Silué, Remi Nono-Womdim, Peter Hanson, Lowell Black, and Tien-cheng Wang. 2010. "Development and Release of Late Blight Resistant Tomato Varieties 'Meru' and 'Kiboko'." International Journal of Vegetable Science 16: 134-47.

Ojiewo, Chris O., Abdou Tenkouano, Jacqueline d'A. Hughes, and JDH (Dyno) Keatinge. 2013. “Diversifying Diets: Using African Indigenous Vegetables to Improve Nutrition and Health." In Diversifying Food and Diets: Using Agricultural Biodiversity to Improve Nutrition and Health, eds. J. Fanzo, D. Hunter, T. Borelli, and F. Mattei Earthscan. Abingdon, UK: Routledge, 291-302.

Oluoch, O. Mel, Florence O. Habwe, Joyce B. Ngegba, Kipkorir R. Koskei, and Ray-Yu Yang. 2012. "Food Preparation and Processing Methods on Nutrient Retention and Accessibility in Selected Indigenous Vegetables from East Africa." Scripta Horticulturae 15: 233-41.

Palermo, Mariantonella, Nicoletta Pellegrini, and Vincenzo Fogliano. 2014. "The Effect of Cooking on the Phytochemical Content of Vegetables." Journal of the Science of Food and Agriculture 94 (6): 1057-70.

Penelope, Nestel, Howarth E. Bouis, J. V. Meenakshi, and Wolfgang Pfeiffer. 2006. “Biofortification of Staple Food Crops." The Journal of Nutrition 136: 1064-67.

Pichop, Germain N. 2007. "Networking to Promote the Sustainable Production and Marketing of Indigenous Vegetables through Urban and Peri-Urban Agriculture in Sub-Saharan Africa." Baseline Production and Marketing Supply Chain Survey Synthesis Report, Tainan, Taiwan: AVRDC-The World Vegetable Center.

Pimentel, David, and Marcia Pimentel. 2003. "“Sustainability of Meat-based and Plant-based Diets and the Environment." American Journal of Clinical Nutrition 78 (3): 660S-3S.

Pray, Carl, Robert Paarlberg, and Laurian Unnevehr. 2007. "Patterns of Political Response to Biofortified Varieties of Crops Produced with Different Breeding Techniques and Agronomic Traits." AgBioForum 10: 135-43.

Schreinemachers, Pepijn, Inokunda Nagaraj, Jacqueline d'A. Hughes, and John D. H. Keatinge. 2014. "Today's Shifting Focus from Hunger to Malnutrition Brings Women to the Forefront of Agricultural Research and Development." New Agriculturalist January: 1-2.

Siegel, Karen R., Mohammed K. Ali, Adithi Srinivasan, Rachel A. Nugent, and K. M. Venkat Narayan. 2014. "Do We Produce Enough Fruits and Vegetables to Meet Global Health Needs?" PLoS ONE 9 (8): e104059. doi:10.1371/journal.pone.0104059

Shakoor, Abdul, Wilson K. Rono, and Eliud K. Ngugi. 1984. "Performance of Early-maturing Determinate Varieties of Green Gram in Semi-arid Areas." East African Agricultural and Forestry Journal 44: 324-26.

Shiferaw, Bekele, Richard Jones, Said Silim, Haile Mariam Teklewold, and Eastonce Gwata. 2007. "Analysis of Production Costs, Market Opportunities and Competitiveness of Desi and Kabuli Chickpeas in Ethiopia. Improving Productivity and Market Success (IPMS) of Ethiopian famers." Project Working Paper 3. Nairobi: ILRI.

Sperling, Louise, Michael E. Loevinsohn, and Beatrice Ntabomvura. 1993. "Rethinking the Farmer's Role in Plant Breeding: Local Bean Experts and On-station Selection in Rwanda." Experimental Agriculture 29: 509-19.

Tenkouano, Abdou. 2011. "The Nutritional and Economic Potential of Vegetables." In State of the World's Food and Agriculture 2011: Innovations that Nourish the Planet. New York: W. W. Norton \& Company, 27-38. 
Tschirley, David, Kavoi M. Muendo, and Michael T. Weber. 2004. “Improving Kenya's Domestic Horticultural Production and Marketing System: Current Competitiveness, Forces of Change, and Challenges for the Future." Working Paper No 08/2004. Nairobi, Kenya: Tegemeo Institute of Agricultural Policy and Development, Egerton University.

Twomlow, S., D. Rohrbach, and J. Dimes, J. Rusike, W. Mupangwa, B. Ncube, L. Hove, Martin Moyo, Nester Mashingaidze, and Putso Mahposa. 2011. “Micro-Dosing as a Pathway to Africa's Green Revolution: Evidence from Broad-scale on-farm Trials." In Innovations as Key to the Green Revolution in Africa, eds. Andre Bationo, Waswa Boaz, Okeyo M. Jeremiah, Maina Fredah, and Kihara Job. Netherlands: Springer, 1101-13.

Vitamin and Mineral Deficiency Report. 2008. Vitamin and Mineral Deficiency: A Partnership Drive to End Hidden Hunger in Sub-Saharan Africa. http://www.micronutrient.org/CMFiles/PubLib/ Report-66-VMD-A-Part-drive-to-end-hidden-hunger-in-Sub-Saharan-Africa1NJF-3242008-6203.pdf. Accessed Aug 1, 2014.

Waudo, Judith, Prisca J. Tuitoek, John Msuya, and Joyce Kikafunda. 2005. "Food Consumption Patterns and Nutrient Intakes by Women and Under Five Children in the Lake Victoria Basin." African Journal of Environmental Studies and Development 1 (1): 40-47.

Weinberger, Kantinka, and Germain Pichop. 2009. “Marketing of African Indigenous Vegetables along the Urban and Peri Urban Supply Chains in Sub-Saharan Africa." In African Indigenous Vegetables in Urban Agriculture, eds. C. Shackleton, M. Pasquini, and A. Drescher. London: Earthscan.

Weinberger, Katinka, Margaret Pasquini, Phyllis Kasambula, and Mary Abukutsa-Onyango. 2011. "Supply Chains for Indigenous Vegetables in Urban and Peri-Urban Areas of Uganda and Kenya: A Gendered Perspective." In Vegetable Production and Marketing in Africa, eds. H. Waibel, and D. Mithöfer. Nairobi, Kenya: CABI.

Woltering, Lennart, Dov Pasternak, and Jupiter Ndjeunga. 2011. "The African Market Garden: The Development of a Low-Pressure Drip Irrigation System for Smallholders in the Sudano-Sahel." Irrigation and Drainage 60: 613-21.

World Health Organization. 1995. “Global Prevalence of Vitamin A Deficiency in Populations at Risk 1995-2005." World Health Organization Global Database on Vitamin A Deficiency. http:// whqlibdoc.who.int/publications/2009/9789241598019_eng.pdf. Accessed August 1, 2014.

- 2002. Nutrition Program: Micronutrient Deficiency Information System, Iron Deficiency Anemia. Geneva, Switzerland: Author.

—. 2013. "WHO Global Database on Vitamin A Deficiency. Vitamin and Mineral Nutrition Information System (VMNIS)." http://www.who.int/vmnis/database/vitamina/en/. Accessed August 1, 2014.

Yang, Ray-Yu, Sarah Fischer, Peter Hanson, and John D. H. Keatinge. 2013. "Increasing Micronutrient Availability from Food in Sub-Saharan Africa with Indigenous Vegetables." In African Natural Plant Products Volume II: Discoveries and Challenges in Chemistry, Health, and Nutrition, eds. Rodolfo H. Juliani, Simon E. James, and Ho Chi-Tang. ACS Symposium Series. Washington, DC: American Chemical Society. 